\title{
A DESJUDICIALIZAÇÃO DA EXECUÇÃo CIVIL NO BRASIL
}

\author{
THE DEJUDICIALIZATION OF CIVIL EXECUTION IN BRAZIL
}

\author{
Flávio Augusto Vilhena Dourado \\ Universidade Federal de Roraima, Boa Vista, RR, Brasil. E-mail: flavioavdourado@gmail.com
}

\section{Douglas Verbicaro Soares}

Universidade Federal de Roraima, Boa Vista, RR, Brasil. E-mail: douglas_verbicaro@yahoo.com.br

DOI: https://doi.org/10.46550/amormundi.v2i5.106

Recebido em: 28.07.2021

Aceito em: 06.08.2021

\begin{abstract}
Resumo: O Poder Judiciário brasileiro enfrenta uma grave crise de eficiência que se concentra, sobretudo, na seara da execução. Dados estatísticos coletados pelo Conselho Nacional de Justiça demonstram que o número de processos em pendência, bem como o tempo médio de tramitaçáo destes, vem crescendo ano após ano. A morosidade que circunda os meios executórios afeta diretamente a prestaçáo jurisdicional e sua capacidade de satisfazer as demandas dos exequentes, por isso, legisladores e estudiosos do Direito buscam uma saída apta a sanar estes vícios. Com eficácia já comprovada em países europeus, dentre os quais encontra-se Portugal, a desjudicialização da execução civil surge como alternativa palpável, afastando do Estado-juiz incapacitado a competência sobre os meios expropriatórios. Panorama esse que resultou na proposição do Projeto de Lei $\mathrm{n}^{\circ}$ 6204, de 2019, que transforma o tabeliáo de protesto em agente de execução, tornando subsidiária a figura do magistrado. Dessa forma, é pertinente questionar: seria a desjudicialização da execuçâo civil capaz de solucionar a crise judiciária no Brasil? O presente estudo científico, de natureza explicativa, tem como escopo desvendar, através de pesquisa bibliográfica, a sua aplicabilidade e efetividade, bem como se o PL n 6204/19 é suficientemente apto a implementar esta reforma.
\end{abstract}

Palavras-chave: Crise judiciária. Congestionamento dos tribunais. Agente de execução. Execução extrajudicial.

Abstract: The brazilian Judiciary is facing a serious efficiency crisis that focuses, mainly, on execution. Statistical data collected by the National Council of Justice show that the number of pending cases, as well as their average processing time, has been growing year after year. The slowness that surrounds execution directly affects the jurisdictional provision and its ability to satisfy the demands of execution creditor, which is why lawmakers and law scholars seek a way out to remedy these vices. With efficacy already proven in European countries, among which is Portugal, a dejudicialization of civil execution as a palpable alternative, removing competence over expropriating means from the incapacitated State. Panorama that resulted in the proposition of Bill No. 6204, of 2019, which turns the notary into an execution agent, making the figure of the magistrate subsidiary. Thus, it is pertinent to ask: would the dejudicialization of civil execution be able to solve the judicial crisis in Brazil? The present scientific study, of an explanatory nature, aims to unveil, through bibliographic research, its applicability and effectiveness, as well as whether Bill No. 6204/19 is sufficiently able to implement this reform.

Keywords: Judicial crisis. Congestion in the courts. Execution agent. Extrajudicial execution. 


\section{Introduçáo}

ma das características ínsitas do Estado Democrático de Direito, ou seja, aquele que
possui como fito principal a salvaguarda das liberdades civis, é, decerto, a facilitação do acesso à Justiça, seja pelo advento da Defensoria Pública, que visa amparar os desafortunados que não tiverem como arcar com advogado particular, além de curatelados especiais, seja pela exponencial conscientizaçáo dos populares acerca de seus direitos. Panorama esse que, a priori, é de todo bom, uma vez que a possibilidade de provocar o Judiciário chega aos menos abastados setores da sociedade. Todavia, como resultado lógico da premissa, tem-se um aumento considerável de litígios, conflitos que antes não eram abarcados pelos tribunais e agora passam a abarrotá-los. Por conseguinte, a efetividade processual sofre a sua maior derrocada.

No Brasil, em específico, a sobrecarga da máquina judiciária, após rápida análise estatística, é evidente. De acordo com o programa "Justiça em Números", operado pelo Conselho Nacional de Justiça, o Poder Judiciário computava um número de 77 milhóes de processos pendentes de baixa ao final de 2019, sendo que mais da metade desses processos (cerca de 55,8\%) se referia à fase de execução (CNJ, 2020). Os comparativos entre a taxa de congestionamento das fases de conhecimento e de execução endossam a ideia de que a crise é executória.

Desafogar a Justiça frente à onda massiva de processos não criminais, parcela majoritária daqueles pendentes em fase executória, passa a ser medida que urge, a fim de amenizar a morosidade e evitar prejuízos à satisfação das demandas (HILL, 2020, p. 198). E uma das maneiras mais arrazoadas e eficazes de se fazer isso é através da desjudicialização da execução civil, um processo que visa transferir para outrem capaz, que não o Estado-juiz, a competência de gerir a etapa executiva.

O emprego de agentes de execução exógenos não deslegitima a ação. Muito pelo contrário, à torna menos dispendiosa para as partes e para o Estado. Com benesses já comprovadas em outras naçôes, surgem no Brasil tentativas de implementar tais ferramentas de desjudicialização, à exemplo do Projeto de Lei n. 6204, de 2019, que disciplina a execução extrajudicial civil para cobrança de títulos executivos judiciais e extrajudiciais e atribui ao tabeliáo de protesto o exercício das funções de agente de execução.

À vista disso, indaga-se: poderia, realmente, a crise de efetividade instalada no Poder Judiciário brasileiro ser contida através da implementação de um sistema executivo desjudicializado?

A presente pesquisa científica terá natureza explicativa, conectando ideias e formulando possíveis soluçóes acerca da problemática de congestionamento em tribunais e analisando se a desjudicialização da execução civil é capaz de corrigir tal disfunção. Através de procedimentos de revisão bibliográfica e estudo documental, submetendo-se à análise doutrina e diplomas legais, visa-se chegar a um resultado qualitativo.

Para isso, far-se-á, no primeiro tópico, uma retrospecção acerca da execução, seguindo até o ordenamento jurídico brasileiro em vigência, com o objetivo de extrair o perfil da problemática de sobrecarga que assola o Poder Judiciário para, somente após isso, na segunda seção, conceituar e elencar as características da desjudicialização da execução civil. 


\section{Breve histórico da execuçáo}

Tucídides de Atenas, historiador da Grécia Antiga, defendia o estudo do passado ao dizer que "os que apreciarem uma informação exata sobre o passado e, por isso mesmo, sobre o futuro (o qual, em virtude da condição humana, será igual ou semelhante), esses a julgarão muito útil, e basta-me saber isso" (BASSELAAR, 1962, p. 20).

Por isso, para o completo entendimento da temática que intitula este trabalho científico, é necessário, antes, construir um esboço histórico da evolução legislativa do Direito Processual, tendo como ponto de partida o Direito Romano, perpassando seus períodos arcaico, clássico e pós-clássico para, enfim, desaguar no direito processual civil brasileiro, pontuando, quando pertinente, os dispositivos legais que regulamentem a atividade de agentes delegados na etapa executória.

\subsection{Execução no Direito Romano: períodos arcaico, clássico e pós-clássico}

Incontestável é, no âmbito do Direito como ciência, a importância de se debruçar sobre os preceitos jurídicos primitivos, pois, como bem afirma Antônio Carlos Wolkmer (2006, p. 02), "[...] na maioria das sociedades remotas, a lei é considerada parte nuclear de controle social, elemento material para prevenir, remediar ou castigar os desvios das regras prescritas”. De tal maneira, mesmo os aglomerados humanos de estruturação tribal possuíam mecanismos para punir civilmente quem descumprisse com os mandamentos legais, ainda que não registrados por escrito.

Indo nesse mesmo sentido, Alexandre Sturion Paula (2008, p. 1) explica que no direito arcaico, na hipótese de descumprimento de determinada obrigação, a execução incidia na pessoa do devedor e não sobre o seu patrimônio, sendo empregadas, em regra, puniçóes físicas que iam desde a escravidão, até morte por esquartejamento. Todavia, para que o credor pudesse aplicar a pena, o crédito deveria ser reconhecido em sentença ou por meio de confissáo. Inclusive, encontra-se precedentes da matéria nas Doze Tábuas, codificação de regras costumeiras publicada por volta do século $\mathrm{V}$ a.C. e considerada o ponto máximo do direito arcaico, sobretudo na Tábua Terceira, que versa sobre a possibilidade de o devedor obter um prazo de trinta dias para pagar caso confessasse a inadimplência perante o juiz.

Como bem diz Álvaro D’Ors:

As normas recolhidas nas Doze Tábuas são fundamentalmente antigos costumes (mores maiorum) da tradição jurídica do Lácio, mas é fora de dúvida que muitos preceitos, como os que estabelecem prazos para determinadas atuações do ius, foram introduzidos pela mesma lei (D'ORS, 1960, p. 15).

Passado o lapso temporal agraciado ao devedor, tínhamos a manus injectio, ação executória de quantia certa, na qual o vencedor da demanda conduzia o vencido perante juízo e o julgador lhe lançava a máo, um gesto que autorizava o credor a levá-lo em cárcere para proceder como bem entendesse (ALVES, 2018, p. 241).

Não há de se estranhar tais costumes pois, há época, os direitos reais figuravam como absolutos e "o propósito da vingança privada era tão somente a retribuição do mal causado" (GRECO, 2017, p. 48), não importando a desproporcionalidade do ato.

Com o passar dos séculos, a tendência de executar sobre o corpo do devedor as penas 
em razão de dívida começou a ser mitigada pelo surgimento de novas leis, com diferentes entendimentos. À exemplo da Lex Poetilia-Papiria, provavelmente do ano 326 a.C., que aboliu o nexum, acordo pelo qual o devedor dava como garantia de empréstimos a sua própria liberdade ou vida, disciplinando, então, sobre a execução do patrimônio do devedor (JUSTO, 2003, p. $51)$.

O historiador Tito Lívio atribui a abolição da escravidão por dívida a um episódio em específico:

Caio Públio se havia entregado a Papírio como escravo para resgatar as dívidas de seu pai. A idade e a beleza do jovem, que deveriam ter provocado a piedade de Papírio, despertaram nele uma paixão viciosa. Considerando a beleza do jovem como um acréscimo de suas riquezas, tratou primeiramente de seduzilo com propostas obscenas. Como Públio permanecesse surdo e desprezasse aquela indignidade, passou a amedrontá-lo com ameaças, relembrando-lhe constantemente sua atual condição. Finalmente, ao ver que ele pensava mais em sua qualidade de homem livre do que em sua situação presente, mandou que o desnudassem e trouxessem as varas. Os bens do devedor, e não seu corpo, responderiam pelas dívidas. Assim, libertaram-se todos os escravos por dívidas e tomaram-se providências para que, daí por diante, nenhum devedor fosse preso (LÍVIO, 1989, p. 181-2).

Embora o autor supracitado ligue a radical mudança a um espírito humanitário que tomara por completo a coletividade romana, há quem permaneça crítico e considere Lex PoetiliaPapiria uma manobra política dos cônsules para abrandar os ânimos da plebe, como é o caso de Peter Brunt que alega que:

Embora o Nexum como um contrato legal fora abolido, servidáo por dívida persistiu no caso de devedores em falta, uma vez que um tribunal poderia conceder aos mutuantes o direito de tornar insolventes devedores como escravos de títulos. Ou seja, a servidão por dívida não desapareceu por completo naquele instante, apenas foi convertida em algo muito mais burocrático (BRUNT, 1971, p. 56-7).

Adentrando no direito clássico, era dos pretores e jurisconsultos, observa-se uma mudança nas relaçôes processuais, como explica Humberto Theodoro Júnior:

O exercício de direito de açáo fazia-se, primeiramente, perante o praetor (agente detentor do imperium), e prosseguia em face do iudex, um jurista, a quem o praetor delegava o julgamento da controvérsia - iudicium)". Doravante, o Estado, em contraponto ao direito arcaico, passa a ter maior participação na solução de lides. No entanto, o pretor, figura que administra a Justiça romana e tem em mãos a supremacia estatal, não poderia por conta própria realizar os julgamentos. Para isso, estava sempre à disposição o particular iudex, a quem eram transpostos os poderes para prolatar sentença (THEODORO JR., 2007, p. 97).

As próprias partes nomeavam o delegado jurisconsulto, que operava em sistema bipartidário. A sentença proferida por este era tão somente um parecer arbitral, devendo, para fins de execução, a parte entrar com nova ação para que o pretor obrigasse o devedor ao adimplemento. Ainda na palavra do autor:

Em Roma o juiz clássico era um particular, sem autoridade para impor a execução de sua sentença que, por isso, apenas "clareava" a situação jurídica das partes, substituindo a obrigação material pela obrigação processual (obligatio iudicati). $\mathrm{O}$ vencedor, por conseguinte, comparecia perante o magistrado (praetor e não mais o iudex) para pedir, em outra açáo, o cumprimento da obligatio iudicati, 
porque só ele tinha o imperium para sancionar o inadimplente (THEODORO JR., 1987, p. 245).

Aqui, o mau pagador não estava totalmente desprovido de defesa porque, acaso houvesse um fiador capacitado, poderia arguir o pagamento do crédito, a extinção da obrigação ou a nulidade da sentença frente ao pretor. Contudo, se improcedente a contestação, a condenaçáo recairia em dobro sobre ele.

Com o passar do tempo, invadindo o direito pós-clássico, iniciado por volta do ano 305, a prestaçáo jurisdicional passou a ser um poder exclusivo do Estado, que concentrava a faculdade de julgar e resolver a lide, sendo excluída a figura do julgador particular.

Tal metamorfose de paradigmas se deve ao engrandecimento da figura do Imperador, que ordenou aos pretores que julgassem com base apenas em fontes normativas atuais, banidas as sentenças fundamentadas em costumes ou leis arcaicas. É o que se chama de extraordinaria cognitio, processo que se desenha e se desenvolve com um só Magistrado (Direito Público), com nova estrutura procedimental e em uma só fase, mas com duplo grau de jurisdição (apellatio), suscetível, ademais, de ser levado a um grau especial (suplicattio).

Percebe-se, então, com este breve apanhado de informaçóes acerca da evolução processual romana, que a competência de executar quantias foi, paulatinamente, abandonando a esfera particular e adentrando na esfera pública. Podemos falar, então, que da época em que a retribuição por dívidas era promovida por particulares de forma desproporcional até a consolidação do Cristianismo em Roma, ocorreu um processo de judicialização da execução civil, o exato contrário do objeto de estudo em questão.

Finaliza-se, de acordo com Ada Pellegrini Grinover (2005, p. 23) "o ciclo histórico da evolução da chamada justiça privada para a justiça pública”. Ou seja, concretiza-se o processo de judicialização, que é o arrastamento dos atos privados para a redoma estatal, fortalecendo o inquebrantável ius imperii.

\subsection{Execução nos primórdios do Direito brasileiro}

Os ordenamentos jurídicos neolatinos derivam diretamente do Direito Romano, e o brasileiro não é exceção. As marcas do modelo pós-clássico extraordinaria cognitio podem ser evidenciadas logo no surgimento do Brasil como Estado independente em 1822, quando fora adotada a mesma legislação de seu país colonizador, as Ordenaçôes Filipinas, cuja vigência em território nacional em matéria civil se deu até 1916.

Conforme explicita Waldemar Martins Ferreira (1952, p. 31-3), a lex romana sobreviveu ao domínio visigótico na Península Ibérica pois os invasores bárbaros incluíram no bojo de suas leis germânicas preceitos do direito romano vulgar. Fato este que permitiu, mesmo após diversas edições das ordenaçôes lusitanas pelos monarcas, que o espírito da execução românica chegasse às terras tupiniquins.

Em resumo, o Código de Felipe II previa, no caso de desrespeito a obrigaçóes de pagar ou de entregar coisa certa, e após condenação perante Juízo, a penhora dos bens do devedor, podendo este ainda ter a sua liberdade cerceada caso náo cumprisse com a ordem judicial. As únicas hipóteses de libertação do cárcere eram o pagamento da dívida, ou a cessão de seus bens.

Importante ressaltar a seguinte peculiaridade: de acordo com as Ordenaçóes Filipinas, 
Livro III, Título LXXXVI, Parágrafo XV, se o valor a ser executado superasse o montante de mil réis, o incumbido pela penhora era o Tabelião ou Escrivão. Porém, sendo inferior a quantia, era o Porteiro o responsável pela tomada. Eram, todos estes, funcionários à mando a Justiça, não descaracterizando, portanto, o caráter público da execução, uma vez que a ordem partia de juiz (PORTUGAL, 1595).

Inobstante a penhora ser dever atrelado à agentes públicos remunerados pelo tribunal, havia, ainda, os depositários e administradores, designados para zelar pelos bens penhorados no caso de não serem entregues diretamente à Justiça, impedindo a depena ou deterioração destes (em sendo coisa certa). Essa qualidade de sujeito em muito se assemelha aos agentes delegados (MEIRELLES, 2011, p. 81).

Em detrimento da legislação importada de Portugal, o primeiro diploma processual nativo do Brasil foi o Regulamento no 737/1850, voltado, a priori, às causas comerciais. Conforme liçôes de Cândido Rangel Dinamarco sobre as naturezas das execuções previstas no Regulamento 737:

As espécies de execução, descritas pelo Regulamento 737, eram apenas (a) a expropriativa (das sentenças ilíquidas e das sentenças líquidas, dizia o regulamento em dois Títulos diversos; arts. 503, 507) e (b) das sentenças sobre ação real ou coisa certa ou em espécie (arts. 571-574). O Regulamento era totalmente omisso quanto à execução forçada das obrigaçóes de fazer ou de não-fazer. Não obstante, havia na prática tal execuçáo, disciplinada por normas (doutrinárias, jurisprudenciais) que bem se aproximavam daquelas contidas no Código de Processo Civil. Não se falava mais nas medidas corporais destinadas a convencer o executado a cumprir tais obrigaçóes (DINAMARCO, 1994, p. 72).

Entende-se por expropriação, segundo doutrina de José Frederico Marques (1998, p. 268) "o ato que importa em alienaçáo ou transferência de bens, que se opera independentemente do consentimento do devedor ou dono desses bens".

Ademais, na nova lei a execução era feita mediante "carta de sentença", excetuando-se os casos previstos nos arts. 476 e 477, colacionados abaixo:

Art. 476. A carta de sentença somente é necessária quando a causa excede a alçada do Juiz.

Si a causa cabe na alçada náo se extrahe sentença, mas mandado executivo em o qual deve ser inserta a sentença do Juiz.

Art. 477. Também não é necessária a sentença, e basta o mandado do Juiz, quando a parte vencida se conforma com a sentença e quer satisfazer a condenação (BRASIL, 1850).

Com isso, tem-se um único título executivo judicial (qual seja, a sentença). Uma análise mais profícua dos dispositivos, porém, revela o que parece ser a primeiríssima previsão de títulos extrajudiciais na história do ordenamento jurídico brasileiro, uma vez que o seu art. 308, \$\$ $1^{\circ}$ a $3^{\circ}$, previa execuçóes persecutórias de títulos provenientes de atos comerciais. Quanto aos agentes competentes náo houve grandes mudanças se comparado o Regulamento às Ordenaçóes Filipinas. Isso porque em seu art. 490 determina o juiz da causa principal como o responsável pela execução.

Embora a penhora continuasse a ser realizada por serventuários da Justiça, mais uma vez pôde ser notada a desjudicialização incidental (aquela que ocorre em apenas alguns atos do 
procedimento) na figura do depositário, particular selecionado para resguardar os bens. Aqui, a descentralização estatal da execução por quantia em si era ainda inexistente.

\subsection{Execução nos Códigos de Processo Civil de 1891 A 1973}

$\mathrm{O}$ início do século XX foi um marco na modernização do direito processual civil, principalmente pelo abandono do sistema legal de provas, conhecido ainda como sistema de provas tarifadas, uma hierarquização pré-definida que obscurecia o livre convencimento do juiz, incapaz de valorar provas por conta própria. A possibilidade de produção de meios probatórios ex officio é outro dos motivos da retirada do julgador o mero status de espectador da vitória do litigante mais hábil. Inicia-se o caminho à era científica do processo civil.

Antes dos acertos, contudo, houve desacertos. Preleciona Theodoro Jr. (2017, p. 30) que, em 1891, a Constituição Republicana estabeleceu uma dicotomia entre a Justiça Estadual e Federal, surgindo, entáo, o direito processual da União e, paralelamente, diversos outros códigos de ordem estadual, quase todos meras adaptaçôes do figurino federal, já que faltava preparo científico por parte dos legisladores para renovar e atualizar o direito processual pátrio, destacando-se táo somente os códigos da Bahia e de São Paulo, que beberam da fonte do moderno direito processual europeu. A ausência de uma sistematização findou por esfacelar o sistema de códigos estaduais, fadado ao fracasso desde o início.

Tomando o acontecido como aprendizado, a Constituição de 1934 instituiu o processo unitário, na forma de seu art. 5', alínea 'a', como bem se pode ver: Art $5^{\circ}$ - Compete privativamente à Uniäo: direito penal, comercial, civil, aéreo e processual, registros públicos e juntas comerciais (BRASIL, 1934).

Por conseguinte, acompanhando o raciocínio de necessidade de consolidar um código processual, no ano de 1937, uma comissão foi encarregada do dever de elaborar o Código Nacional de Processo Civil, não conseguindo os legisladores concluir seu objetivo por conta de incontornáveis divergências (ORTEGA, 2010). Pedro Batista Martins, um dos membros da comissão que se encarregou em 1937 de elaborar o Código Nacional de Processo Civil, aproveitando o estabelecimento da unidade legislativa em matéria processual, elaborou individualmente um projeto que mais tarde foi transformado em lei (Decreto-Lei 1.608, de 1939), entrando em vigor a partir de $1^{\circ}$ de fevereiro de 1940 (MARQUES, 1958, p. 134).

Neste Código "coexistiam uma parte geral moderna, fortemente inspirada nas legislaçôes alemã, austríaca, portuguesa e nos trabalhos de revisão legislativa da Itália, e uma parte especial anacrônica, ora demasiadamente fiel ao velho processo lusitano, ora totalmente assistemática" (BERMUDES, 2006, p. 218). O novo Código trazia uma parte geral moderna ao mesmo tempo em que continha uma parte especial antiquada (THEODORO JÚNIOR, 2007, p. 17).

O Decreto-Lei 1.608, de 1939, firmava um sistema dual, havendo simultaneamente as chamadas açóes executivas e o processo de execução. Aquela primeira, fruto do banimento da assinação de dez dias, se dava por meio de procedimento sincrético. Depois de ocorrido o ajuizamento da lide e citação do devedor, seguia-se à penhora, suscetível, contudo, à contestação. Elencadas no art. 298 do Decreto-Lei, seriam processadas pela forma executiva as seguintes açóes: dos serventuários de justiça, para cobrança de custas, contadas na conformidade do respectivo regimento; dos intérpretes, ou tradutores públicos, para cobrança dos emolumentos taxados em regimento; dos corretores, para cobrança das despesas e comissóes de corretagem, e dos leiloeiros 
ou porteiros, para a das despesas e comissóes das vendas judiciais; dos condutores, ou comissários de fretes; dos procuradores judiciais, médicos, cirurgiōes-dentistas, engenheiros e professores, para cobrança de seus honorários, desde que comprovada inicialmente. ou no curso da lide, a prestação do serviço contratado por escrito; dos credores por dívida garantida por cauçáo judicial ou hipoteca; dos credores por obrigaçóes ao portador (debentures), por letras hipotecárias, e "coupons" de juros de ambos esses títulos; do credor pignoratício, mediante depósito prévio da coisa apenhada, salvo a hipótese de não ter havido tradição, dente outras.

O processo de execução, por sua vez, configurava-se como execução pura, aplicada mediante prolação de sentença condenatória, como previsto nos arts. 882, inciso I e 290, ou, ainda, em títulos judiciais mencionados em dispositivos esparsos. Destaca-se, portanto, que na ação declaratória, a sentença que passava em julgado valia como preceito, mas a execução do que houver sido declarado somente poderia promover-se em virtude de sentença condenatória. Quanto à competência, ponto de maior relevância para nosso estudo, Dinamarco (1994, p. 77) explicita que, em relação ao processo de execução, ela era atribuída ao órgão jurisdicional que tivesse conduzido o processo de conhecimento originariamente. Já a açáo executiva, obedecia às regras ordinárias.

Persistindo desde o Regulamento no 737, a figura do particular depositário seguiu nas entrelinhas da legislação. Quando havia negação por parte do credor de estabelecer no processo o executado como fiel depositário, os bens tinham como destino, ou instituição financeira pública; ou depositário desjudicializado, quando não havia, na sede do juízo, depósito público ou estabelecimento bancário (art. 945, III, do Decreto-Lei 1.608, de 1939).

Importante dizer que o texto proposto por Pedro Martins não apenas seguiu esta tendência do Regulamento, como fez surgir nova espécie de desjudicialização incidental, ao possibilitar que o magistrado, na ausência de avaliador judicial no juízo, nomeasse livremente um particular para cumprir o mandado de avaliação (art. 487, $\$ 2^{\circ}$, do Decreto-Lei 1.608, de 1939).

Os conflitos da Segunda Guerra Mundial ocasionaram um grande êxodo ao território brasileiro, geograficamente distante das zonas belicosas. E nestas colunas de imigrantes vieram, também, doutrinadores do Direito, em especial italianos, destacando-se Enrico Tullio Liebman, responsável por fundar a Escola Processual de São Paulo. Por meio dela, Liebman auxiliou no desenvolvimento do direito processual como ciência autônoma de outros ramos do direito. Notável é a influência de seus ensinamentos sobre Alfredo Buzaid, professor da Faculdade de Direito de Sáo Paulo incumbida da elaboraçáo do anteprojeto do novo Código de Processo Civil. Extremamente teórico e dogmático, ao melhor estilo itálico, surgiu o Código de 1973.

Não se tratava mais do aproveitamento de diplomas legais anteriores, com o objetivo de meramente reformá-los. O Código Buzaid, como fora chamado, firmou uma revolução no direito, consagrando a tríplice divisão do processo civil: processo de conhecimento, processo de execução e processo cautelar (NUNES, 2015). Daquele que interessa para este trabalho científico, o de execução, aponta-se como maiores mudanças a equiparaçáo dos títulos extrajudiciais aos judiciais. Um verdadeiro trabalho de saneamento que aboliu a atrasada ação executiva, permeada de atos cognitivos do mérito. Liebman (1963, p. 05) conclui que "o conceito moderno de função jurisdicional abrange necessariamente também a execução como atividade não simplesmente complementar da cognição e sim como parificada com esta em importância prática e interesse científico". 
Em relação à possibilidade de atuação de agentes desjudicializados no âmbito do processo, o CPC/73 elencava estes, de forma genérica e juntamente com demais serventuários de ordem estritamente pública, no art. 139, no Capítulo V, "Dos auxiliares da Justiça”. Podemos citar dentre eles, o perito avaliador, o depositário particular e o administrador (BRASIL, 1973).

A hipótese de avaliador particular encontra guarida legal no art. 475-J, $\$ 2^{\circ}$, do $\mathrm{CPC} / 73$, consubstanciando-se, basicamente, na incapacidade técnica do oficial de justiça para proceder com a avaliaçáo, cabendo ao juiz a nomeação de um terceiro capaz, com conhecimentos especializados, assinando-lhe breve prazo para a entrega do laudo. Em dispositivo posterior, art. 680, há o adendo de que tal prazo não ultrapassará 10 (dez) dias (BRASIL, 1973).

O depositário de natureza particular, por sua vez, tem previsão no art. 666, I e III, do CPC/73. Primeiramente, estabelece-se a viabilidade de depósito dos bens penhorados, sejam pedras e metais preciosos, quantias ou papéis de crédito, em qualquer estabelecimento de crédito, designado pelo juiz, na falta de agências das quais o Estado-Membro da União possua mais de metade do capital social integralizado. O inciso III é ainda mais explícito, citando por expresso o depositário particular como responsável para guarda de bens residuais (BRASIL, 1973).

Se, por acaso, a penhora recair em estabelecimento comercial, industrial ou agrícola, bem como em semoventes, plantaçóes ou edifício em construção, o depositário passará a figurar como administrador, sendo nomeado pelo juiz e obrigado a apresentar plano de administração no prazo de 10 (dez) dias, conforme art. 677, caput. Está resguardado às partes, porém, o direito de apontar o depositário administrador, caso em que a escolha será homologada pelo juiz, de acordo com o parágrafo $2^{\circ}$ do inciso supracitado (BRASIL, 1973).

Todavia, de acordo com Marcos Neves Fava (2009) existiam crises no processo de execuçáo: uma crise interpretativa, derivada de uma mudança no contexto social, alimentando a visão de que o devedor merece ser defendido, quando, na realidade, o lesado é o credor. Como aponta Paulo Henrique dos Santos Lucon (2000, p. 424), "o ambiente sociológico alterou-se. Nos dias de hoje, ser devedor não é mais um grave defeito e não pagar as próprias dívidas deixou de seu um sinal de vergonha”.

Havia, também, a crise ontológica, que seria uma crise de eficácia, na qual o devedor dificulta a intervenção do Estado em seu universo patrimonial, dilapidando os bens passíveis de execução; e a crise estrutural, onde os feitos judiciais demoram mais para livrar-se dos procedimentos executórios do que para os recursos serem apreciados, "eternizando" a fase de execução e desperdiçando a celeridade que a fase de conhecimento conseguiu alcançar.

Como já dito, pragmático e doutrinário, o Código de Processo Civil de 1973 foi alvo de reformas, todas elas "alteraçôes voltadas à praticidade, seja instituindo normas exteriores a ele, e destinadas todas a agilizar a efetividade dos direitos pela via do processo (no tocante à execução forçada, as inovações vieram na Lei n. 8953, de 13.12.94)" (DINAMARCO, 1994, p. 83).

A recorrência com que o Código de 1973 vinha sendo submetido a constantes emendas acabou por gerar, nos últimos tempos, um clima de desconfiança, com sérias repercussóes sobre o sentimento de segurança jurídica em torno da prestação jurisdicional civil. Com isso, veio a aprovação da Lei 13.105, de 16.03.2015. 


\subsection{Atual Regramento (NCPC/15)}

Por volta de 2010, o movimento reformador, a fim de restaurar a estabilidade perdida pelo código repleto de remendos (embora reconhecida a sua qualidade técnica), que causava incerteza quanto à segurança jurídica, submeteu ao Congresso Nacional o Projeto Legislativo no 166/2010, de iniciativa da Presidência do Senado Federal, um ambicioso plano que visava instaurar nova codificação processual civil no país. O fim de sua tramitação deu-se apenas quatro anos depois, mais especificamente em 17.12.2014, data em que o Senado aprovou na íntegra a redação do que viria a se tornar a Lei no 13.105 , de 16 de março de 2015, o Novo Código de Processo Civil.

Ao relembrar os fatos que rodearam a formulação do texto legal, Theodoro Júnior fala que:

A Comissão de Juristas, nomeada pela Presidência do Senado, orientou-se, na elaboração do Anteprojeto, pelos princípios universalmente preconizados para as leis processuais, que aspirem a dotar o Estado Democrático de Direito de um processo justo, e que se apresentam, na ordem constitucional, como a garantia a todos de acesso a uma tutela efetiva. Como tal, entende-se aquela que, a par de viabilizar a composição de conflitos com total adequação aos preceitos do direito material, o faça dentro de um prazo razoável e sob método presidido pelas exigências da economia processual, sempre assegurando aos litigantes o contraditório e a ampla defesa (CF, art. 5, LXXVIII) (THEODORO JR., 2017, p. 25-26).

Portanto, o NCPC/15 representou um grande avanço na democratização da Justiça, fortalecendo o princípio da equidade e ampliando o acesso a ela. Inclusive, em suas motivaçóes, o Anteprojeto expunha que "um sistema processual civil que não proporcione à sociedade o reconhecimento e a realização dos direitos, ameaçados ou violados, que têm cada um dos jurisdicionados, não se harmoniza com as garantias constitucionais de um Estado Democrático de Direito" (BRASIL, 2010).

Embora não se possa negar o caráter inovador do Código em diversos sentidos, não houve significativas modificaçôes quanto ao monopólio judicial da execução, bastante pontuais as alteraçôes nesse campo.

Marcus Vinicius Rios Gonçalves (2017) fala sobre a dedicação do Livro II da Parte Especial, do NCPC/2015, ao processo de execução. A execução civil faz-se por duas maneiras no ordenamento jurídico nacional: como uma fase subsequente ao processo de conhecimento, na qual tenha sido proferida sentença condenatória, não cumprida de forma voluntária; ou como processo autônomo quando fundada em título executivo extrajudicial.

De forma expressa, o art. 783 do NCPC/2015 conserva os requisitos essenciais da execução, em principal a exigibilidade de apresentar-se título executivo que represente obrigação certa, líquida e exigível. Por conseguinte, no art. 786, veja-se que só há execução mediante inadimplemento, situação comissiva ou omissiva através da qual o devedor não cumpre sua obrigação. Portanto, o órgão jurisdicional só concederá a tutela executiva para o credor, aqui exequente, que apresentar título executivo e afirmar que a sua pretensão se encontra insatisfeita (BRASIL, 2015).

Conforme Marcelo Abelha:

Sempre que não houver o cumprimento espontâneo da obrigação ou do dever 
legal nascido de uma relação jurídica entre dois sujeitos, ou quando não houver cooperação (positiva ou negativa) de um sujeito decorrente de uma sujeição a um respectivo direito potestativo, nascerá, nesses dois casos, para o titular do sujeito ativo, um direito à obtenção da satisfação, in concreto, do direito que ele possui (ABELHA, 2015, p. 223).

A depender da natureza da prestação devida, o diploma legal divide a execução em espécies distintas, didaticamente separadas em capítulos: execução para a entrega de coisa (Capítulo II); execução de obrigações de fazer ou de não fazer (Capítulo III); execução por quantia certa (Capítulo IV); execução contra a Fazenda Pública (Capítulo V); e execução de alimentos (Capítulo VI) (BRASIL, 2015).

Atualmente, todos os atos processuais executivos emanam do poder do Estado-juiz, e têm como finalidade satisfazer a pretensão do exequente, sujeitando o executado a essa finalidade, sendo realizados mediante técnicas processuais de sub-rogação ou coercitivas, como dispóe o artigo 139, inciso IV da Lei 13.105/15:

Art. 139. O juiz dirigirá o processo conforme as disposições deste Código, incumbindo-lhe:

IV - determinar todas as medidas indutivas, coercitivas, mandamentais ou subrogatórias necessárias para assegurar o cumprimento de ordem judicial, inclusive nas açóes que tenham por objeto prestação pecuniária (BRASIL, 2015);

Por meios sub-rogatórios, o Estado-juiz substitui a atividade do executado, prescindindo sua vontade e realizando o direito do exequente. Com incrível poder de síntese, Dinamarco (2004, p. 47) explica que estas são "medidas realizadas por um sujeito, o juiz, em substituição à conduta de outro sujeito, que é o obrigado inadimplente (sub-rogar, em direito, é pôr no lugar de)”. Ou seja, se persegue resultado idêntico, ou resultado prático equivalente, àquele que deveria ser realizado pelo devedor.

Os meios coercitivos, doutra maneira, são aqueles que não prescindem da vontade do executado, pois atuam diretamente sobre ela, com função coercitiva de pressão psicológica, como um estimulante positivo no cumprimento da obrigação inadimplida, tendo grande vantagem sobre os anteriores, pois possuem menos custo e ônus, tanto para o Estado quanto para o exequente.

Falar-se-á, agora, das formas de constrição judicial (perdimento forçado pelo Estado da faculdade de dispor livremente de coisa) previstas no Novo Código, já largamente abordadas nas codificaçôes antecessoras.

Ao analisar a Seção III do NCPC/15, percebe-se que, em relação à penhora, pouco mudou, acrescidos alguns ritos específicos para penhoras de dinheiro em depósito ou em aplicação financeira (art. 854), de quotas ou açóes de sociedades personificadas e de percentual de faturamento de empresa (art. 835, incisos IX e X, respectivamente). Em resumo, a essência da penhora e os seus procedimentos basilares foram conservados, modernizando o texto apenas quanto aos objetos da execução (BRASIL, 2015).

Com o depósito foi um pouco diferente, em razão da supressão do depositário particular, antes previsto no art. 666, III, do CPC/73. Embora mantidas as hipóteses de depósito em estabelecimento de crédito designado pelo juiz e, nos mesmos termos da legislação anterior, o depositário-administrador (agora no art. 862), a retirada do depositário particular da redação se 
faz um decréscimo na desjudicialização.

Dentre as atualizaçôes promissoras, nesse sentido, encontradas no NCPC/15, destacase a possibilidade de as partes selecionarem perito avaliador mediante requerimento, conforme o art. 471, devendo haver também a indicação dos assistentes técnicos que irão acompanhar a perícia. O parágrafo $3^{\circ}$ do dispositivo dispóe que, caso seja a indicação das partes consensual, ela substituirá a nomeação feita pelo magistrado (BRASIL, 2015), indicando um brevíssimo afastamento do controle mantido pelo juiz.

No âmbito da expropriação, derradeira etapa da execução por quantia certa, que seria a desapropriação forçada em si, o NCPC/15 a divide da seguinte maneira:

Art. 825. A expropriação consiste em:

I - adjudicação;

II - alienação;

III - apropriação de frutos e rendimentos de empresa ou de estabelecimentos e de outros bens (BRASIL, 2015).

A adjudicação é a maneira expropriatória preferencial, ocorrendo após a efetiva penhora dos bens do executado, devendo ser expressamente requerida pelo exequente (de forma oral ou escrita), estando vedado o juiz de decidir por ela de ofício. Contudo, o exequente não deve oferecer preço inferior ao da avaliação, na forma do art. 876, do CPC/15.

Doravante, se tem a alienação, que seguindo os preceitos encontrados no art. 879, do novel Estatuto Processual Civil, será feita por iniciativa particular ou em leiláo judicial eletrônico ou presencial, no caso de não efetivada a adjudicação (art. 880) (BRASIL, 2015). Imperioso é dizer que esta última hipótese se define como forma de desjudicialização incidental, visto que os leiloeiros são considerados agentes delegados.

Todas as formas de desjudicialização incidental comentadas anteriormente, que cobrem tão somente atos específicos, nem de longe proporcionam a efetividade que pode proporcionar a desjudicialização do procedimento integral.

Apesar das melhorias trazidas pela mais recente legislação processual, os entraves não desapareceram por completo. Os tribunais engessados e sua morosidade intrínseca continuam a ferir a expectativa de satisfatividade, ainda que o regramento vigente pareça ser o mais justo e cientificamente acertado possível.

\section{A desjudicializaçáo na execuçáo civil}

Finda a retrospectiva que abarcou desde os tempos imemoriais, quando a execução de dívida se dava por inflicçôes à carne do devedor, até o direito processual brasileiro moderno, no qual não se almeja nada além da justa reparação, torna-se oportuno adentrar na temática da desjudicialização da execução civil, técnica de aceleração do processo. Não sem antes, por óbvio, expor as justificativas do porquê ela se faz necessária, coisa que só se pode fazer ao demonstrar os problemas que a precedem. 


\subsection{A problemática do congestionamento nos tribunais brasileiros}

É de saber comezinho o quão demorado pode ser um processo civil no Brasil, algo curiosamente implantado na mentalidade coletiva que, sem ao menos se dar conta do significado originário da palavra, relaciona o termo "burocracia” com "demora”. Ocorre que há uma justificativa plausível para tal, o que se pode observar por meio de estudos estatísticos da Judiciário nacional, em específico o Relatório Justiça em Números, construído anualmente pelo Conselho Nacional de Justiça com as minúcias do desempenho dos tribunais espalhados pelo país, sejam estaduais ou federais.

Trazendo à tona o mais recente deles, publicado em 2020 pelo Conselho Nacional de Justiça, contendo dados coletados no ano-base 2019, logo nos deparamos com uma seçáo exclusiva para tratar do acesso à justiça, esmiuçando a demanda populacional pelos serviços judiciais e as concessóes de assistência judiciária gratuita. Acesso à justiça é, basicamente, "o sistema por meio do qual os cidadáos e cidadãs podem reivindicar seus direitos e/ou solucionar litígios sob os auspícios do Estado" (FILHO, 2006, p. 48).

Tomando como amostra apenas os processos de conhecimento e de execução de títulos extrajudiciais, eliminando da conta as execuçôes judiciais iniciadas, infere-se que, a cada grupo de 100.000 habitantes, aproximadamente 12.211 tenham ingressado com uma ação judicial em 2019 (CNJ, 2020).

Este cenário só é possível porque nosso ordenamento foi na contramão do sistema laissez-faire, modelo político liberal de não-intervenção estatal, filosofia de cerne individualista. Theodoro Júnior versa com primor sobre:

Nessa época, em que prevalecia como máxima dominante o laissez-faire, todos eram solenemente presumidos iguais e a ordem constitucional se restringia a criar mecanismos de acesso à Justiça, sem maiores preocupaçóes com sua eficiência pratica ou efetiva. Diferenças econômicas ou institucionais nem sequer eram cogitadas pelo ordenamento jurídico. Os problemas reais dos indivíduos não chegavam a penetrar no campo das preocupaçóes doutrinarias em torno do Direito Processual (THEODORO JÚNIOR, 1997, p.49).

Embora no passado a autotutela fosse a regra, hoje, através do aumento dos meios informativos, o acesso à justiça passa não só a ser factível, como crescente. Flávia Pereira Hill descreve esse fenômeno como hiperjudicialização:

Hoje, precisamos fazer frente ao que nós preferimos chamar de hiperjudicialização, para designar a contingência atual em nos deparamos com um volume assustador (e ainda crescente) de ações judiciais em tramitação perante o Poder Judiciário, fruto da preferência, quase que automática, da sociedade contemporânea pela adjudicação estatal para a solução dos litígios, não raro antes mesmo de ensaiar o mais comezinho contato direto com o outro litigante para a tentativa de obtenção da solução consensual (HILL, 2020, p. 171).

Uma demanda como essa exige uma prestação jurisdicional equivalente. De acordo com o Relatório Justiça em Números 2020, no ano anterior os índices de produtividade dos magistrados (IPM) e dos servidores (IPS-Jud) sofreram uma variaçáo positiva de, respectivamente, $13 \%$ e 14,1\%. Quanto ao volume médio sob gestão dos juízes foi de 6.962, perfazendo um aumento de 13\%. Estes é a maior performance praticada pelos magistrados em 11 anos. De 2009 a 2019, o IPM teve uma alta de 32,5\%, um recorde (CNJ, 2020). 
Tais levantamentos levam a crer que o Judiciário tem uma melhora e pode se desafogar em breve. Todavia, esse pensamento revela-se errôneo quando postos sob a nossa lupa de estudo os gargalos da execução.

Tomando como referência o mesmíssimo relatório estatístico, nota-se que entre os anos de 2009 e 2017, os casos pendentes em fase de execução apresentaram uma tendência de crescimento, o que não mudou em 2019. Enquanto ao final de 2018 o número de processos de execução que tramitavam condiziam a 54,2\% de um total de 79 milhões, em 2019 essa porcentagem passou a ser de 55,8\% de 77 milhóes (CNJ, 2020).

Tão alarmante é, que as execuções chegaram a consumir mais de 60\% do acervo de alguns tribunais, como: TRF3 na esfera federal; e TJRJ, TJSP, TJDFT e TJPE na estadual. Logicamente, a taxa de congestionamento na execuçáo, que mede a efetividade de determinado tribunal em um período, transcreve na tabela igual crescendo, superando em muito a taxa de congestionamento nos processos de conhecimento. Em ordem decrescente, as maiores taxas de congestionamento na execução em todo o país são: TRF1, com 91,1\%; TJAM, com 88,8\%; e TRT2 com 83,8\% (CNJ, 2020).

É claro que quando o Conselho Nacional de Justiça se refere à execução, estão inclusas também todas aquelas de natureza fiscal e criminal. Por isso, é imprescindível isolar as informaçóes que buscamos. No ano-base, os casos pendentes de execuçóes não fiscais dentre todas aquelas de ordem extrajudicial, foram 3.138.385. E os casos pendentes de execuçôes não criminais dentre todas aquelas de ordem judicial, foram 7.911.479.

Por mais que a maior fatia dos demonstrativos se refiram à execução fiscal, certamente se tolhêssemos parte dos processos de execução civil através de ferramentas de desjudicialização, o respiro para o Poder Judiciário seria significativo. Acerca da tramitação, o Relatório descreve que o tempo médio dos processos pendentes e baixados na fase de execução de $1^{\circ}$ grau no Poder Judiciário são, respectivamente, 6 anos e 9 meses, e 5 anos e 11 meses (CNJ, 2020).

Infelizmente, os dados reunidos pelo CNJ não possuem caráter crítico. Eles apenas demonstram, de forma bastante simples, as atividades exercidas pelos tribunais durante um ano, sem propor melhorias ou maneiras de contornar as problemáticas.

Nessa linha, Heitor Vitor Mendonça Sica considera necessária a utilização dos dados da Justiça disponíveis para aperfeiçoamento legal, antes do prático, "afinal, não é porque alteraçóes legislativas não são aptas a sozinhas, resolver o mau funcionamento do processo que simplesmente devam ser descartadas como instrumento a serviço da melhoria da eficiência da distribuição de justiça”" (SICA, 2013, p. 210).

A ineficácia latente do Poder Judiciário na seara executiva demonstra que não se está a ofertar ao exequente a melhor forma de satisfazer a sua demanda. Marinoni fala sobre a busca do cumprimento das decisóes prolatadas em sede do processo judicial que são pressupostas por um meio executivo congruente:

Acontece que a sentença que reconhece a existência de um direito, mas não é suficiente para satisfazê-lo, não é capaz de expressar uma prestação jurisdicional efetiva, uma vez que não tutela o direito e, por isso mesmo, não representa uma resposta que permita ao juiz se desincumbir do seu dever perante a sociedade e os direitos. Diante disso, não há dúvida que a tutela jurisdicional só se aperfeiçoa, nesses casos, com a atividade executiva. Portanto, a jurisdição não pode significar 
mais apenas "iuris dictio" ou "dizer o direito", como desejavam os juristas que enxergam na atividade de execução uma mera função administrativa ou uma "função menor". Na verdade, mais do que direito à sentença, o direito de ação, hoje, tem como corolário o direito ao meio executivo adequado (MARINONI, 2008, p. 112).

A descomedida morosidade opera como uma afronta a uma série de princípios resguardados pela Carta Magna, dentre eles o princípio da eficiência, previsto no art. 37 , da $\mathrm{CF} / 88$, e o princípio da razoável duração do processo e celeridade, de acordo com o art. $5^{\circ}$, LXXVIII, da CF/88, que, em conjunto, fazem nascer o direito à efetividade, como esclarece Teori Albino Zavascki:

Sob a denominação de direito à efetividade da jurisdição queremos aqui designar o conjunto de direitos e garantias que a Constituição atribui ao indivíduo que, impedido de fazer justiça por máo própria, provoca a atividade jurisdicional para vindicar bem da vida de que se considera titular. A este indivíduo devem ser, e são, assegurados meios expeditos e, ademais, eficazes, de exame da demanda trazida à apreciação do Estado. Eficazes, no sentido de que devem ter aptidão de propiciar ao litigante vitorioso a concretização 'Tática' da sua vitória (ZAVASCKI, 1997, p. 64).

Em busca de compreender as mazelas que rondam a Justiça brasileira, Feitosa (2007, p. 3139) aponta dez fatores como causas da morosidade no Poder Judiciário: crescimento da demanda, falta de recursos materiais, carência de recursos humanos, legislação inadequada, inoperância do legislativo e do executivo, formalismo, procedimentos arcaicos e barreiras burocráticas, excesso de recursos e o duplo grau de jurisdiçáo, prazos especiais para o Poder Público e o despreparo dos profissionais do Direito.

A Justiça, então, além de lenta é dispendiosa. O Relatório Justiça em Números revela que em 2019 as despesas totais do Poder Judiciário somaram mais de R\$ 100,2 bilhóes, aproximadamente $1,5 \%$ do Produto Interno Bruto (PIB), representando 2,7\% dos gastos anuais da União. Houve um aumento de 2,6\% no uso de recursos financeiros em relação à 2018 (CNJ, 2020).

O monopólio e a inafastabilidade da jurisdição, que deveriam ser elementos edificadores da soberania do Estado, findam por alimentar os vícios aqui apontados. De uma perspectiva mais clássica e restrita, Canotilho, ao analisar a possibilidade de atuação de órgãos extrajudiciais na resolução de conflitos de interesses em detrimento da reserva de jurisdição, afirma que:

[...] a expressa rejeiçẫo constitucional de 'auto-defesa', de "justiça privada" ou "justiça pelas próprias mãos" (excepcionando apenas alguns casos de direito de resistência) implica necessariamente a atribuição da realização concreta do direito, com fim de solucionar litígios, a órgãos imparciais particularmente qualificados; os órgãos/poder especialmente qualificados para estas funções de jurisdictio devem ter o monopólio da jurisdição, pois isso é uma dimensão ineliminável do princípio do estado de direito e um corolário material do princípio da divisão de poderes; o monopólio jurisdicional é hoje, seguramente, um princípio constitucional material concretizador ou densificador destes princípios (CANOTILHO, 2003, p. 668).

No Estado Constitucional, tal visão não há de prevalecer, pois as relações conflitantes poderão ser apaziguadas de forma heterocompositiva ou autocompositiva. "Há heterocomposição quando um terceiro resolve a ameaça ou crise de colaboração na realização do direito material entre 
as partes. Há autocomposição quando as próprias partes resolvem seus conflitos" (MARINONI, 2016, p. 187). Afastar a jurisdição do Estado, mesmo que momentaneamente, é possível.

Por isso, é necessário desenvolver técnicas para contornar tais crises. Basicamente, através do redirecionamento do processo para a satisfação do interesse do credor e da aplicação de medidas mais práticas para a efetividade da execuçáo. A medida deve ser a mais célere, a mais efetiva e a mais simples possível, qualidades próprias da execução desjudicializada.

\subsection{Desjudicialização: Conceito e pontuais ocorrências na Legislação Especial Pátria}

Compilados os déficits do Poder Judiciário e suas prováveis causas, é inevitável a busca por soluçôes. Vejamos que, a cada reformulação da codificação processual civil no país, tentou-se aprimorar a fase de execução com enfoque na redução de tempo e despesas, e embora devamos admitir o primor do $\mathrm{CPC} / 15$ em relação aos seus antecessores, os danos à satisfatividade da demanda persistiram. Por sorte, não existe causa perdida no mundo, estando o remédio ao nosso alcance.

Repisando a possibilidade de se afastar da Justiça a capacidade de prestar tutela jurisdicional, preconiza Theodoro Júnior:

É certo que o acesso à tutela jurisdicional tem caráter de garantia fundamental. O que, entretanto, não mais prevalece é que essa tutela seja prestada exclusivamente pelo Poder Judiciário. O Poder Público não pode deixar de propiciá-la ao titular do direito lesado ou ameaçado, o que, entretanto, poderá ser feito tanto pela justiça estatal como por outros organismos credenciados pela lei. É claro que, afinal, o Poder Judiciário conservará o controle de legalidade sobre a atuação desses organismos extrajudiciais (THEODORO JÚNIOR, 2020).

Este entendimento é a matriz da ideia de "desjudicialização da execução civil". Ainda que a doutrina pareça não se importar tanto com a conceituação precisa deste termo, ela é, em sentido amplo, "a concentraçáo de atos do procedimento executivo sob responsabilidade de terceiros externos ao Poder Judiciário" (CIRLUZO, 2016, p. 29).

Ada Pellegrini Grinover (2005, p. 33) define a desjudicialização da execução como uma "desformalização enquanto tendência processual, quando se trata de dar pronta solução aos litígios, constituindo fator de celeridade". Isso porque deixa-se de lado, aos poucos o sistema formal de execução, que é aquele jurisdicionalizado.

Logo, é sobre delegar ou retirar atribuições, competências, decisôes e parte da jurisdição do Estado-juiz para serventias extrajudiciais ou quaisquer entidades privadas, como pode se extrair dos ensinamentos de Joel Dias Figueira Júnior (2014, p. 579). Diferentemente da desjudicialização incidental (que abrange apenas alguns atos do procedimento, quando o juiz atribui atividades típicas para terceiros, à exemplo de serventuários do cartório do tribunal), identificável até mesmo nas Ordenaçôes Filipinas, a desjudicialização que nos importa demanda a dispensa total, ou em alto grau, da máquina judiciária, tal qual, em analogia, se dá a descentralização no Direito Administrativo.

Em nota de rodapé, Cirluzo (2016, p. 31) vê como descartável a tese de Umberto Bara Bresolin que distingue desjudicialização executiva de execução extrajudicial. Para Bresolin (2013, p. 53-67), aquela primeira tratar-se-ia da redução da jurisdição, em maior ou menor grau, mas sem a total exclusão do juiz, enquanto a segunda seria, essa sim, o potencial afastamento total da 
figura do magistrado dos atos relativos à satisfação do exequente.

Uma vez que a desjudicialização dos meios executórios visa sanar deficiências do Poder Judiciário como um todo, e não apenas de seus agentes, membros ou servidores, nos valeremos do conceito segundo o qual ela se dá através da dispensa total ou majoritária (com isso, refere-se a um aspecto quantitativo acerca de sua incidência sobre os procedimentos) do juiz.

Ao tratar da temática, inferindo sobre o impacto do surgimento do ramo executivo não-jurisdicional e a possibilidade de coexistência com o sistema formal, Daniela Olímpio de Oliveira preceitua:

A desjudicialização está mais afeita a uma situação - o movimento de retirada de procedimentos que antes eram típicos da função judicial, sendo agora absorvidos por outras instâncias não judiciais. Em verdade, pode-se manter a coexistência dos meios, ou não. Tềm-se, assim, procedimentos que são mesmo excluídos da apreciação judicial, e outros que passam a ser assumidos também pela processualidade administrativa ou cartorária (OLIVEIRA, 2014, p. 163).

Logo, o fenômeno da judicialização, iniciado há séculos e que continua nos dias de hoje, que compreende o crescimento no espectro de decisóes, inclusive de natureza política, da ocupação do Poder Judiciário, coexiste com o fenômeno da desjudicialização, tendo em vista que ambos são alimentados continuamente pelas transformaçôes sociais. Explicando a duplicidade de resultados dessas mudanças ocorridas na coletividade, Diógenes Hassan Ribeiro evidencia que:

Estas, a par de contribuírem para a judicialização, também servem à desjudicialização. Num momento impóem a judicialização; noutro momento a desjudicialização. No primeiro, evidenciam a deficiência do Legislativo e entáo fazem com que a demanda seja solucionada jurisdicionalmente. No outro instante, promovem a desjudicialização porque o Estado-juiz não consegue apresentar uma solução eficaz. Como visto, a sociedade não espera a solução legislativa do Estado-legislador, nem a solução jurídica por via do Estado-juiz. A sociedade faz e acontece. A sociedade é o motor da evolução dos sistemas sociais. Nesses termos, tanto a judicialização como a desjudicialização decorrem de causas naturais e até acidentais, imprevistas e incontidas (RIBEIRO, 2013, p. 32).

Por mais que o modelo executivo judicializado seja preponderante, existem procedimentos esparsos no ordenamento nacional que avançaram em direção à desjudicialização, encontrados, sobretudo, em legislação especial. Dentre as mais dignas de atenção, estão as seguintes: Decretolei no 70/1966, que autoriza o funcionamento de associaçóes de poupança e empréstimo, institui a cédula hipotecária e dá outras providências; e Lei 9.514/1997, que trata do Sistema Financeiro Imobiliário/Alienação Fiduciária de bem imóvel.

Há de se dizer que a constitucionalidade desses diplomas fora posta em dúvida por diversas vezes, sendo a matéria, inclusive, levada ao Supremo Tribunal Federal, que nunca vislumbrou quaisquer violaçôes.

Veja-se, por exemplo, a ementa do acordão lavrado pelo Ministro Relator Ilmar Galvão, no Recurso Extraordinário 223.075-1/DF, onde, à grosso modo, se questionava a recepção do Decreto-lei no 70/1966 pela Constituição Federal de 1988, conforme cita Joel Dias Figueira Júnior:

A execução extrajudicial de contratos de compra e venda regidos pelo Sistema Financeiro da Habitação, prevista no Dec.-lei 70/66, náo ofende as normas dos 
incisos XXXV, XXXVII e LII do art. 50 da CF, de molde a configurar ruptura do monopólio do Poder Judiciário, uma vez que, além de prever uma fase de controle judicial, antes da perda da posse do imóvel pelo devedor, não impede que eventual ilegalidade perpetrada no curso do procedimento de venda do bem seja reprimida pelos meios processuais próprios (FIGUEIRA JÚNIOR, 2014).

O Decreto-lei no 70/1966, além de instituir a cédula hipotecária, permite, nos termos de seu art. 31, quando vencida e náo paga a dívida hipotecária, no todo ou em parte, o credor executá-la de acordo com este diploma, formalizando a solicitação de execução da dívida ao agente fiduciário, vinculado ao Sistema Financeiro da Habitação.

$\mathrm{O}$ agente fiduciário aqui abordado nada mais é do que um terceiro particular selecionado pelas partes de comum acordo no momento do contrato de hipoteca. A priori, deveria este ser credenciado no Banco Central do Brasil, nas condiçóes que o Conselho Monetário Nacional viesse a autorizar.

Porém, a função só recebeu a devida regulamentação anos depois com a Resolução no 1.745/90, elencando no seu artigo $2^{\circ}$ como capazes de exercê-la os bancos múltiplos, bancos comerciais, bancos de investimento, bancos de desenvolvimento, Caixa Econômica Federal, sociedades de crédito, financiamento e investimento, sociedades de crédito imobiliário, associaçôes de poupança e empréstimo, companhias hipotecárias, sociedades corretoras de títulos e valores mobiliários e sociedades distribuidoras de títulos e valores mobiliários. Quase que como a corrigir o Decreto-lei no 70/1966, a Resolução no 1.745/90 isentou os agentes fiduciários da indigência de se credenciarem no Banco Central (BACEN, 1990).

Após verificar que o requerimento e os documentos apresentados pelo credor encontramse livres de irregularidades, o agente protocola notificação extrajudicial no Cartório de Títulos e Documentos com endereçamento ao devedor, que tem por única saída pagar as parcelas em atraso. "Não acudindo o devedor à purgação do débito, o agente fiduciário estará de pleno direito autorizado a publicar editais e a efetuar no decurso dos 15 (quinze) dias imediatos, o primeiro público leiláo do imóvel hipotecado", antevê o art. 32, caput, do Decreto-lei no 70/1966 (BRASIL, 1966).

A legislação foi largamente criticada porque parte da doutrina acreditava que seus dispositivos instituíam espécie de autotutela, uma execução processada pelo próprio credor.

Com o declínio do Sistema Financeiro de Habitação, tentativa do Governo de facilitação de crédito para construção de moradias, adveio a Lei 9.514/1997, instituindo o Sistema Financeiro Imobiliário e possibilitando ao credor fiduciário a alienação de bem imóvel perante inadimplência, conforme o dispositivo abaixo colacionado:

Art. 22. A alienação fiduciária regulada por esta Lei é o negócio jurídico pelo qual o devedor, ou fiduciante, com o escopo de garantia, contrata a transferência ao credor, ou fiduciário, da propriedade resolúvel de coisa imóvel.

$\S 1^{\circ}$ A alienação fiduciária poderá ser contratada por pessoa física ou jurídica, náo sendo privativa das entidades que operam no SFI, podendo ter como objeto, além da propriedade plena:

I - bens enfitêuticos, hipótese em que será exigível o pagamento do laudêmio, se houver a consolidação do domínio útil no fiduciário;

II - o direito de uso especial para fins de moradia; 
III - o direito real de uso, desde que suscetível de alienação;

IV - a propriedade superficiária.

$\$ 2^{\circ}$ Os direitos de garantia instituídos nas hipóteses dos incisos III e IV do $\$$ 1 o deste artigo ficam limitados à duração da concessão ou direito de superfície, caso tenham sido transferidos por período determinado (BRASIL, 1997).

Dessa forma, defronte ao desrespeito do devedor para com suas obrigaçôes, o fiduciário encaminha requerimento ao Cartório de Registro de Imóveis, a fim de intimá-lo a pagar no prazo de quinze dias. Conforme ensina Cirluzo (2016, p. 111), ainda que o Oficial do Cartório não interfira no mérito das parcelas ou no cálculo da dívida, tem por incumbência exercer o controle de legalidade do requerimento, colocando sob análise seus aspectos formais. Na hipótese de, após intimado, o devedor purgar a mora, ficará a cargo do Oficial receber os valores, descontando os custos referentes ao procedimento e, no prazo de três dias, os entregando ao credor.

Neste ponto, é necessário atentar-se aos mandamentos da Constituição Federal de 1988 acerca da atividade notarial e de registro:

Art. 236. Os serviços notariais e de registro são exercidos em caráter privado, por delegação do poder público.

$\S \mathbf{1}^{\mathbf{0}}$ Lei regulará as atividades, disciplinará a responsabilidade civil e criminal dos notários, dos oficiais de registro e de seus prepostos, e definirá a fiscalização de seus atos pelo Poder Judiciário.

§ 20 Lei federal estabelecerá normas gerais para fixação de emolumentos relativos aos atos praticados pelos serviços notariais e de registro.

§ 30 O ingresso na atividade notarial e de registro depende de concurso público de provas e títulos, não se permitindo que qualquer serventia fique vaga, sem abertura de concurso de provimento ou de remoção, por mais de seis meses (BRASIL, 1988).

O Oficial cartorário é, portanto, mais um particular a permear a execução, sendo responsável por importantes atos, bem como dispóe ele próprio de certo controle de legalidade. Decerto, a falta de meios de defesa à disposição do devedor no teor da lei levanta, à primeira vista, certa desconfiança. Porém, repisa-se o fato de que não há quaisquer impedimentos para que eventual ilegalidade perpetrada no curso do procedimento seja reprimida pelos meios processuais próprios. Ou seja, não se resignando à intimação extrajudicial, o devedor poderá provocar o judiciário, até então alheio ao conflito, por meio de ação autônoma.

$\mathrm{O}$ intuito original dos legisladores ao implantarem os procedimentos desjudicializados aqui apontados era claramente desenvolvimentista. E para desenvolver é preciso desburocratizar. Esse é o escopo de qualquer medida desjudicializadora: redução de complexidade. Não estavam o Decreto-lei no 70/1966 e a Lei 9.514/1997, apesar disso, livres de falhas. As acusaçóes de facilitação à autotutela não são de todo infundadas (FABRÍCIO, 2021).

As teses de inconstitucionalidade suscitadas, mesmo que não abraçadas pela jurisprudência do Supremo Tribunal Federal, servem de aprendizado para a modernização da desjudicialização, devendo os óbices serem contornados para que a máxima praticidade seja atingida sem desrespeitar princípios processuais básicos.

Dando um salto temporal, observa-se que na última década a tendência desjudicializadora não desapareceu, tampouco enfraqueceu. Pelo contrário, parcela dos doutrinadores empenha-se 
em encontrar a fórmula precisa que teria pleno funcionamento no Brasil, com especial enfoque na figura do tabelião, agente delegado de alta confiabilidade que pode facilmente ser fiscalizado, ou corrigido, pelo Poder Judiciário (RIBEIRO, 2013, p. 43).

O elemento faltante para que se opere tal reforma no âmbito da execução por quantia seria, portanto, a devida regulamentaçáo legal em território nacional. Nesse sentido, há muito a se aprender com as experiências de desjudicializaçáo estrangeiras, cujos pontos positivos podem ser absorvidos e os negativos, abstraídos.

\section{Consideraçóes finais}

Como pôde-se ver, a execução civil nacional tem suas raízes fincadas no Direito Romano, onde, a priori, os meios executórios eram praticados por particulares e recaíam sobre os corpos dos devedores, dando ensejo à aplicação das penas de mutilação e escravidão. Todavia, por conta de um processo de judicialização, a Administraçáo Pública passou a concentrar de forma paulatina tais funçóes, afastando-as da esfera privada, consolidando o ius imperii.

Embora o Estado brasileiro tenha absorvido e conservado esta característica em seu ordenamento através do princípio da reserva de jurisdição, a modernidade apresentou novos desafios, todos eles provenientes do congestionamento dos tribunais, onde ao menos 55,8\% dos processos em tramitação encontram-se na fase executória. Analisadas as taxas de pendência na Justiça como um todo, incluídas as esferas federal e estadual, torna-se evidente que o cerne da crise é a ineficiência da execução.

A fim de amenizar as problemáticas que assolam o Poder Judiciário, como a morosidade processual e as despesas estratosféricas utilizadas na manutenção das ações, surge como solução a desjudicializaçáo. Trata-se, basicamente, da concentraçáo de atos do procedimento executivo sob responsabilidade de terceiros, agentes aos quais o Estado-juiz cede seus poderes natos. Há vastas experiências estrangeiras a servirem de inspiração para uma possível reforma no Brasil, sobretudo, o sistema executivo português, que tornou a figura do magistrado subsidiária a do solicitador, profissional liberal capaz de expropriar bens para purgar a mora de pagamento e satisfazer uma demanda.

Constatou-se que, com as devidas adaptaçôes às condiçôes sociopolíticas do país, o modelo lusitano poderia embasar a implementação de um sistema desjudicializado no Brasil. O que logo se mostrou verdade com o advento do Projeto de Lei 6204/19, tentativa de desjudicializar a execução civil baseada em títulos executivos judiciais e extrajudiciais através da inclusão dos tabeliães de protesto como agentes executivos. Não obstante os diversos empecilhos apontados, a proposta legislativa é totalmente hábil a sanar os vícios que rondam os tribunais, já que uma grande parcela de dispendiosos procedimentos seria exercida por serventias extrajudiciais.

O número de tabelionatos dessa espécie espalhados pelo território brasileiro é bastante satisfatório para a finalidade do PL 6204/19, sem falar que os mesmos estão dotados de profissionais capacitados, selecionados por meio de concurso público, bem como de vastos recursos monetários para cumprir os encargos executórios. Embora em alguns sistemas estrangeiros desjudicializados tais incumbências sejam exercidas por advogados, no Brasil, a advocacia é incompatível com as atividades desenvolvidas no cartório de protesto. Com isso percebe-se que o Projeto de Lei em discussão está em completo acordo com a realidade brasileira. 
Destarte, o presente estudo científico conclui que o afastamento dos procedimentos executivos civis da alçada judicial e sua devida assimilaçáo pelos tabelionatos de Protesto de Títulos é totalmente factível e constitucional, diante da metamorfose do conceito de jurisdição e necessidade de se respeitar os princípios da eficiência e da razoável duração do processo e celeridade. Conforme defende o douto professor Humberto Theodoro Jr., o aperfeiçoamento do sistema extrajudicial se dará apenas após a sua vigência, através de análise de dados.

\section{Referências}

ABELHA, Marcelo. Manual de execução civil. 5. ${ }^{\mathrm{a}}$ ed. rev. e atual. - Rio de Janeiro: Forense, 2015.

ALVES, José Carlos Moreira. Direito Romano. 18 a ed. Rio de Janeiro: Forense, 2018.

BANCO CENTRAL DO BRASIL. Resolução 1764, de 1990. Disponível em: <https://www. bcb.gov.br/pre/normativos/res/1990/pdf/res_1764_v4_L.pdf>. Acesso em: 21 de julho de 2021.

BASSELAAR, Joseph Jacobus van den. Heródoto, o pai da História. Revista de História, vol. 24, n. 49, ano 13. São Paulo: USP, 1962. BRASIL. Anteprojeto do Novo Código de Processo Civil, 2010.

BERMUDES, Sergio. Introdução ao processo civil. $4^{\mathrm{a}}$ ed. Rio de Janeiro: Editora Forense, 2006.

BRASIL. Decreto $n^{\circ} 737$, de 25 de Novembro de 1850. Disponível em: <http://www.planalto. gov.br/ccivil_03/decreto/historicos/dim/DIM0737.htm >. Acesso em: 20 de março de 2021.

BRASIL. Constituição da República dos Estados Unidos do Brasil (de 16 de julho de 1934). Disponível em: <http://www.planalto.gov.br/ccivil_03/constituicao/constituicao34.htm>. Acesso em: 20 de julho de 2021.

BRASIL. Decreto-lei no 1.608, de 18 de setembro de 1939. Disponível em: <http://www. planalto.gov.br/ccivil_03/decreto-lei/1937-1946/del1608.htm>. Acesso em: 20 de julho de 2021.

BRASIL. Lei no 5.869, de 11 de janeiro de 1973. Disponível em: <http://www.planalto.gov.br/ ccivil_03/leis/15869impressao.htm >. Acesso em: 20 de julho de 2021.

BRASIL. Anteprojeto do novo Código de Processo Civil. Disponível em: <https://www2.senado. leg.br/bdsf/handle/id/496296 >. Acesso em: 20 de julho de 2021.

BRASIL. Lei no 13.105, de 16 de março de 2015. Disponível em: <http://www.planalto.gov.br/ ccivil_03/_ato2015-2018/2015/lei/113105.htm>. Acesso em: 20 de julho de 2021.

BRASIL. Decreto-Lei no 70, de 21 de novembro de 1966. Disponível em: <http://www.planalto. gov.br/ccivil_03/decreto-lei/del0070-66.htm>. Acesso em: 21 de julho de 2021.

BRASIL. Lei no 9.514, de 20 de novembro de 1997. Disponível em: <http://www.planalto.gov. br/ccivil_03/leis/19514.htm>. Acesso em: 21 de julho de 2021.

BRASIL. Constituição da República Federativa do Brasil (1988). Disponível em: <http://www. 
planalto.gov.br/ccivil_03/constituicao/constituicao.htm>. Acesso em: 11 de julho de 2021.

BRESOLIN, Humberto Bara. Execução extrajudicial imobiliária: aspectos práticos. São Paulo: Atlas, 2013.

BRUNT, Peter Astbury. Conflitos Sociais na República Romana. Chatto \& Windus Ltd. Londres: 1971.

CANOTILHO, J. J. Direito constitucional e teoria da Constituição. 7. ed. Coimbra: Almedina, 2003.

CILURZO, Luiz Fernando. A desjudicialização na execução por quantia. 2016. Tese de Doutorado. Universidade de São Paulo.

CONSELHO NACIONAL DE JUSTIÇA. Justiça em Números 2020. Disponível em: $<$ https://www.cnj.jus.br/pesquisas-judiciarias/justica-em-numeros/>. Acesso em: 11 de julho de 2021.

DINAMARCO, Cândido Rangel. Execução Civil. 4a ed. São Paulo: Malheiros, 1994.

DINAMARCO, Cândido Rangel. Instituiçóes de direito processual civil IV. São Paulo: Malheiros, 2004.

D’ORS, Álvaro. Elementos de direito privado romano. Pamplona: Studium Generale, 1960.

FABRÍCIO, Adroaldo Furtado. A alienação fiduciária de imóveis: aspectos processuais da Lei $n$. 9514/97. Disponível em: < http://www.fabricioadvogados.com.br/artigos/art8.htm>. Acesso em: 06 julho. 2021.

FAVA, Marcos Neves. Execução trabalhista efetiva. São Paulo: LTr, 2009.

FEITOSA, Antonio Alcy Cordeiro. Do Poder Judiciário: A morosidade no âmbito da Justiça Estadual. Fortaleza: Universidade Estadual Vale do Acaraú, 2007.

FERREIRA, Waldemar Martins. História do Direito Brasileiro, V. II. Rio de Janeiro: Livraria Freitas Bastos, 1952.

FIGUEIRA JÚNIOR, Joel Dias. Execução civil e temas afins - do CPC/1973 ao novo CPC. São Paulo: Ed. RT., 2014, p. 576-604

FIGUEIRA JÚNIOR, Joel Dias. Desjudicialização da Execução Civil. Disponível em: <https:// www.migalhas.com.br/depeso/330308/desjudicializacao-da-execucao-civil >. Acesso em: 11 de julho de 2021.

FILHO, José Bittencourt. Acesso à justiça: por onde passa a desigualdade. In: ALMEIDA, Eneá Stutz e. (Org). Direitos e garantias fundamentais. Florianópolis. Fundação Boiteux, 2006.

GONÇALVES, Marcus Vinicius Rios. Direito processual civil esquematizado. 8. ed. São Paulo: Saraiva, 2017.

GRECO, Rogério. Curso de direito penal: parte geral. 19. ed. Rio de Janeiro: Impetus. 2017.

GRINOVER, Ada Pellegrini, et. al. Teoria Geral do Processo. 21 ed., São Paulo: Mallheiros 
Editores, 2005.

HILL, Flávia Pereira. Desjudicialização da Execução Civil: reflexôes sobre o projeto de Lei no 6.204/2019. Revista Eletrônica de Direito Processual, v. 21, 2020.

JUSTO, António Santos. A evolução do direito romano. Coimbra: Boletim da Faculdade de Direito da Universidade de Coimbra, v. 75, 2003.

LIEBMAN, Enrico Tullio. Processo de execução. São Paulo: Saraiva, 1963.

LÍVIO, TITO. História de Roma. São Paulo, Editora Paumape S.A., 1ª ed. 1989.

LUCON, Paulo Henrique dos Santos. Eficácia das Decisóes e Execução Provisória. São Paulo: Editora Revista dos Tribunais, 2000.

MARINONI, Luiz Guilherme. Curso de processo civil: teoria geral do processo. São Paulo: RT, 2008

MARINONI, Luiz Guilherme. Novo curso de direito processual civil: teoria do processo civil. v.1. 2. ed. São Paulo, 2016.

MARQUES, José Frederico. Instituiçóes de Direito Processual Civil. 1ª ed. Rio de Janeiro: Editora Forense, 1958.

MARQUES, José Frederico. Manual de Direito Processual Civil. 2a Edição. Campinas/SP: Editora Millennium, 1998.

MEIRELLES, Hely Lopes. Direito Administrativo Brasileiro. 37a ed. São Paulo: Malheiros, 2011.

NUNES, Camila. Do Código Buzaid ao novo Código de Processo Civil: uma análise das influências culturais sofridas por ambas as codificaçôes. Revista de Processo, ano 40, vol. 246. São Paulo: Instituto Brasileiro de Direito Processual, 2015.

OLIVEIRA, Daniela Olímpio de. Desjudicialização, acesso à justiça e teoria geral do processo. Curitiba: Juruá, 2014.

ORTEGA, Carlos Eduardo. Novo CPC deve atender realidade brasileira. Consultor Jurídico, 2010. Disponível em: <https:/www.conjur.com.br/2010-fev-28/cpc-estar-sintonia-sociedadebrasileira-atual>. Acesso em: 20 de julho de 2021.

PAULA, Alexandre Sturion. Cognição e Império Diante da Nova Sistemática da Tutela Executiva. Disponível em: <http://sisnet.aduaneiras.com.br/lex/doutrinas/arquivos/011007.pdf> Acesso em: 29 de julho de 2021.

PORTUGAL. Decreto-lei no 38/2003. Disponível em: <https://dre.pt/home/-/dre/220944/ details/maximized>. Acesso em: 08 de julho de 2021.

PORTUGAL. Decreto-lei no 226/2008. Disponível em: <https://dre.pt/web/guest/pesquisa/-/ search/439815/details/maximized> Acesso em: 08 de julho de 2021.

PORTUGAL. Portaria no 282/2013. Disponível em: <https://www.pgdlisboa.pt/leis/lei_ mostra_articulado.php?nid=1968\&tabela=leis\&so_miolo=> Acesso em: 08 de julho de 2021. 
PORTUGAL. Lei no 41/2013. Disponível em: <https://dre.pt/web/guest/legislacaoconsolidada/-/lc/107055833/201706160100/73437147/diploma/indice> Acesso em: 08 de julho de 2021.

RIBEIRO, Diógenes Hassan Ribeiro. Judicialização e desjudicialização: entre a deficiência do legislativo e a insuficiência do judiciário. Revista de Informação Legislativa, Ano 50, n. 199, jul./ set. Brasília: Senado Federal, 2013.

RIBEIRO, Flávia Pereira. Desjudicialização da execução civil. São Paulo: Saraiva, 2013.

SENADO FEDERAL. Projeto de Lei $n^{\circ}$ 6204, de 2019. Disponível em: <https://www25. senado.leg.br/web/atividade/materias/-/materia/139971 >. Acesso em: 11 de julho de 2021.

THEODORO JÚNIOR, Humberto. As Novas Reformas do Código de Processo Civil. 2a. ed. Rio de Janeiro: Editora Forense, 2007.

THEODORO JÚNIOR, Humberto. Curso de direito processual civil. $v$. 1. 46. ed. Rio de Janeiro: Forense, 2007.

THEODORO JÚNIOR, Humberto. A execução de sentença e a garantia do devido processo legal. Rio de janeiro: AIDE, 1987.

THEODORO JÚNIOR, Humberto. Curso de Direito Processual Civil - Teoria geral do direito processual civil, processo de conhecimento e procedimento comum. vol. I, 58. ed. Rio de Janeiro: Forense, 2017.

THEODORO JÚNIOR., Humberto. Projeto Legislativo de Desjudicialização da Execução Civil. Disponível em: <https:/www.migalhas.com.br/depeso/332358/projeto-legislativo-dedesjudicializacao-da-execucao-civil $>$. Acesso em: 12 de julho de 2021.

WOLKMER, Antônio Carlos. Fundamentos de História do Direito. Belo Horizonte, Editora Del Rey ltda, 3a ed. 2006.

ZAVASCKI, Teori Albino. Antecipação da Tutela. São Paulo: Saraiva, 1997. 